\title{
Blistering skin reaction with Mastisol in a patient with spina bifida: illustrative case
}

\author{
Robin M. Bowman, MD, ${ }^{1,2}$ Vineeth Thirunavu, BA, ${ }^{1,2}$ and Sandi Lam, MD, MBA',2 \\ ${ }^{1}$ Division of Pediatric Neurosurgery, Ann and Robert H. Lurie Children's Hospital of Chicago, Chicago, Illinois; and 'Department of Neurosurgery, Northwestern University \\ Feinberg School of Medicine, Chicago, Illinois
}

BACKGROUND Patients with spina bifida have repeated interactions with the healthcare system and often require multiple surgeries throughout their lifetime. Latex precautions are often indicated owing to the high risk of anaphylactic reactions. The choice of dressing for these patients represents an opportunity for learning and standardization if appropriate. The authors discuss the various cases of skin reactions to Mastisol in the literature in comparison with their case and explore the possible mechanisms underlying this skin reaction given the high prevalence of latex allergy in patients with spina bifida.

OBSERVATIONS The authors present the case of a 17-year-old girl with a history of spina bifida and shunted hydrocephalus who underwent a shunt externalization operation and subsequently developed an allergic contact dermatitis reaction to Mastisol liquid adhesive. Topical steroid cream was then administered, and signs and symptoms resolved over the next 3 days.

LESSONS The choice of dressing should be considered carefully in patients with spina bifida given their repeated exposures and possible sensitivities. The authors aim to increase the awareness of the possibility of Mastisol-induced skin reactions in patients with spina bifida and set a foundation for future studies to investigate the relationship between latex allergy and sensitization to Mastisol.

https://thejns.org/doi/abs/10.3171/CASE2011

KEYWORDS spina bifida; Mastisol; allergic contact dermatitis; latex; myelomeningocele; neural tube defect

Patients with spina bifida make up $0.1 \%$ of the population ${ }^{1}$ and have repeated interactions with the healthcare system, often requiring multiple surgeries during their lifetimes owing to neurological, orthopedic, and urological problems. ${ }^{2}$ Latex precautions are instituted at birth because patients with spina bifida have a high risk for severe intraoperative anaphylactic reactions to latex. ${ }^{3}$

In the course of the multiple surgical procedures, the choice of dressing is an opportunity for learning and for standardization if appropriate. We report on an acute skin reaction to Mastisol (Eloquest Healthcare) in a patient with spina bifida and develop the rationale to link this back to the universal latex precautions instituted in the spinal bifida population. We share this case and a report of the literature as a shared learning opportunity for those who take care of patients with spina bifida.

\section{Illustrative Case}

A 17-year-old girl with a history of spina bifida and shunted hydrocephalus presented to the pediatric neurosurgical service at
Ann and Robert H. Lurie Children's Hospital of Chicago with ventriculopleural shunt malfunction, shortness of breath, and pleural effusion that necessitated shunt externalization. At the start of surgery, ChloraPrep (Becton, Dickinson and Company) 2\% chlorhexidine gluconate/70\% isopropyl alcohol solution was used widely on the skin over the left side of the head and neck and bilateral chest. The shunt was externalized at the level of the clavicle. Subcutaneous tissue was approximated with Ethicon Vicryl and an epidermal layer closed with nylon. The wound was covered with bacitracin ointment and gauze. Mastisol liquid adhesive was applied under the entire area of a medium-sized $4.4 \times$ 5 -inch Tegaderm dressing (3M). The externalized shunt tubing was laid out in a strain loop configuration and the Tegaderm placed over it. No other adhesives or products came in contact with the skin. One day after surgery, an erythematous blistering skin reaction was noted under the Tegaderm, where Mastisol was applied, in the exact shape of contact with the substance (Fig. 1). Of note, the patient had no adverse reaction to Mastisol in multiple prior

ABBREVIATIONS ACD = allergic contact dermatitis; $\mathrm{CTB}=$ compound tincture benzoin INCLUDE WHEN CITING Published March 29, 2021; DOI: 10.3171/CASE2011.

SUBMITTED September 22, 2020. ACCEPTED December 14, 2020.

(c) 2021 The authors, CC BY-NC-ND 4.0 (http://creativecommons.org/licenses/by-nc-nd/4.0/) 


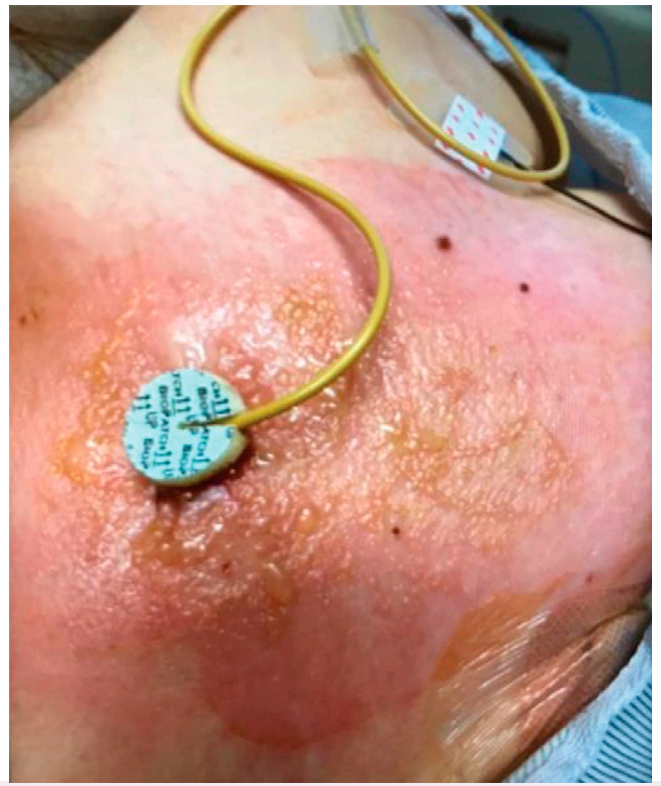

FIG. 1. ACD reaction 1 day after use of Mastisol.

exposures. She was also placed on latex precautions since birth because of a presumed severe anaphylactic reaction to latex during attempted spinal fusion when she was a young child. There was local pain and itching. There was no skin abnormality where only Tegaderm was applied, such as the

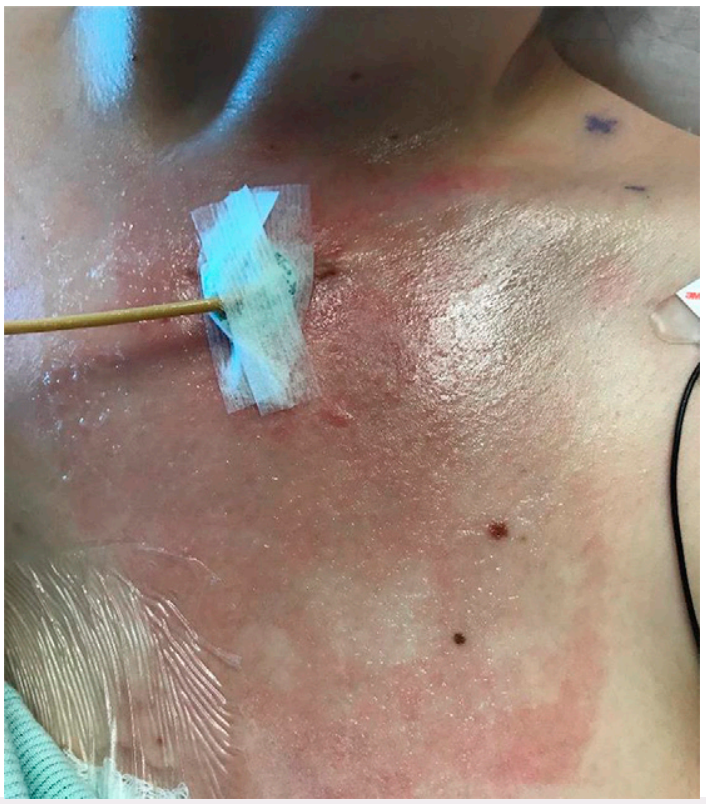

FIG. 2. Resolving skin reaction 2 weeks after use of Mastisol.

intravenous access sites of the forearms. This led to a suspicion of an allergic contact dermatitis (ACD) reaction to Mastisol. The blisters evolved to rupture, and the skin was kept clean. Signs and symptoms resolved over the next 3 days with a topical steroid cream (Fig. 2).

\section{TABLE 1. Summary of ACD reactions to Mastisol cases in the literature}

\begin{tabular}{|c|c|c|c|c|c|c|c|}
\hline $\begin{array}{l}\text { Author \& } \\
\text { Year }\end{array}$ & $\begin{array}{l}\text { Patient } \\
\text { Age } \\
\text { (yrs)/ } \\
\text { Sex }\end{array}$ & Procedure & $\begin{array}{l}\text { Site of Skin } \\
\text { Reaction }\end{array}$ & $\begin{array}{l}\text { Description of Skin } \\
\text { Reaction }\end{array}$ & Other Details & Treatment & Resolution \\
\hline $\begin{array}{l}\text { Ezeh et al., } \\
2018^{4}\end{array}$ & 20/M & $\begin{array}{l}\text { Single-event } \\
\text { multilevel soft-tissue } \\
\text { surgery to optimize } \\
\text { function of It upper } \\
\text { extremity }\end{array}$ & $\begin{array}{l}\text { Lt wrist dorsal/ } \\
\text { volar, It cubital } \\
\text { fossa }\end{array}$ & $\begin{array}{l}\text { Acute blistering \& } \\
\text { dermatitic eruption }\end{array}$ & $\begin{array}{l}\text { Developed severe } \\
\text { cutaneous allergic } \\
\text { reaction after 3rd } \\
\text { exposure to } \\
\text { Mastisol }\end{array}$ & $\begin{array}{l}\text { Hydroxyzine, oral } \\
\text { prednisone, oral } \\
\text { cephalexin, wound } \\
\text { dressing changed twice } \\
\text { daily }\end{array}$ & $\begin{array}{l}\text { All signs of ACD } \\
\text { resolved by } 3 \text { wks } \\
\text { postop }\end{array}$ \\
\hline $\begin{array}{l}\text { Kline, } \\
2008^{5}\end{array}$ & $37 / F$ & Foot surgery & $\begin{array}{l}\text { Rt dorsal foot/ } \\
\text { toes }\end{array}$ & $\begin{array}{l}\text { Blistering, edema, \& } \\
\text { erythema }\end{array}$ & $\begin{array}{c}\text { Patient had } \\
\text { penicillin \& sulfa } \\
\text { drug allergies \& } \\
\text { history of } \\
\text { childhood asthma }\end{array}$ & $\begin{array}{l}\text { Removal of tapes \& } \\
\text { solution, saline wash, } \\
\text { oral Benadryl, Medrol, } \\
\text { cool compress }\end{array}$ & $\begin{array}{l}\text { Local blistering, } \\
\text { edema, \& } \\
\text { erythema } \\
\text { resolved in 3-5 } \\
\text { days }\end{array}$ \\
\hline $\begin{array}{l}\text { Mabrie \& } \\
\text { Papel, } \\
1999^{12}\end{array}$ & $36 / F$ & Revision rhinoplasty & $\begin{array}{l}\text { Entire nose w/ } \\
\text { extensions to } \\
\text { both cheeks }\end{array}$ & $\begin{array}{l}\text { Maculopapular, } \\
\text { erythematous rash }\end{array}$ & $\begin{array}{c}\text { Had undergone } 4 \\
\text { previous } \\
\text { rhinoplasties }\end{array}$ & $\begin{array}{l}\text { Oral methylprednisone, } \\
\text { topical hydrocortisone }\end{array}$ & $\begin{array}{l}\text { Resolution of all } \\
\text { symptoms \& } \\
\text { discoloration by } 6 \\
\text { wks postop }\end{array}$ \\
\hline
\end{tabular}


Referral to dermatology and subsequent patch testing revealed that the patient was allergic to Mastisol (strong positive) and bacitracin (weak positive). No reactions to Tegaderm, chlorhexidine, povidoneiodine solution, or surgical metals were noted. The patient was provided with a list of materials that are safe to use in case of future surgeries.

\section{Discussion}

\section{Observations}

Since Mastisol was approved for use in 1963, there have been 5 case reports in the literature of an ACD reaction to Mastisol (Table 1). One was in the orthopedic setting, in which a 20-year-old man with 2 previous exposures (2 and 7 years prior) to Mastisol with no documented history of adverse reactions. He developed a severe cutaneous allergic reaction after his 3 rd exposure to Mastisol. ${ }^{4}$ Our patient also had no documented history of an adverse reaction to Mastisol in prior exposures, suggesting an allergen sensitization mechanism in these patients. Additionally, the diagnosis of an acute ACD reaction to Mastisol was similarly made given the distinct pattern of blistering in the area where Mastisol was applied. Patch testing was not conducted in either patient, and the specific ingredient of Mastisol causing the reaction was not pinpointed.

It is possible that the gum mastic and styrax ingredients of Mastisol are responsible for the skin reactions in our patient. In another case of an ACD reaction to Mastisol in a 37-year-old woman undergoing foot surgery, patch testing revealed that Mastisol itself was responsible for the allergy since the sites containing only DuraPrep (3M) and the Steri-Strips (3M) were nonreactive. ${ }^{5}$ The contact allergen was theorized to be the gum mastic, styrax, or methyl salicylate ingredients in Mastisol. In another case, patch testing in a 59year-old woman after an ACD reaction to Mastisol showed clear reactions to the gum mastic and storax ingredients in Mastisol. ${ }^{6}$ Both gum mastic and storax are resins obtained from tree sap. Patients with spina bifida, including our patient, are placed on latex precautions because of the numerous procedures and repeated exposures to latex. ${ }^{7}$ Of note, latex is also obtained from tree sap and is composed of resins, proteins, water, and other ingredients.

Although latex and rubber chemicals do not have ingredients that overlap with Mastisol, it is possible that there is cross-reactivity between the allergens in both owing to similar proteins, such as those found in balsam of Peru and Mastisol. This may explain the acute contact dermatitis reaction to Mastisol in this patient with spina bifida. Anecdotally, other patients with spina bifida may have had this type of reaction to Mastisol at our institution in the past, but it was not clearly documented. It is also possible that latex allergy sensitizes individuals to Mastisol with an unclear mechanism. Latex allergy in patients with spina bifida has been associated with an increased risk for type 1 hypersensitivity reactions like anaphylaxis during general anesthesia, ${ }^{8}$ but there has not been an association noted with type 4 hypersensitivity reactions like $A C D$. Directions for future investigation may include testing to see if certain risk factors for latex allergy and latex sensitization in patients with spina bifida are related to ACD reactions to Mastisol. For instance, testing could look for specific antibodies to latex over $3.5 \mathrm{kU} / \mathrm{L}$, frequently positive latex skin prick tests, elevated total antibodies, and positive radioallergosorbent test to fresh foods. ${ }^{7}$

\section{Lessons}

The choice of dressing should be considered carefully in patients with spina bifida given their repeated exposures and possible sensitivities. With this case and additional research, we posit that Mastisol should be used with caution in patients with spina bifida, who may have adverse skin reactions. Ideally, patch testing should be conducted to pinpoint the specific ingredient(s) that the patient is allergic to so that other products with the same ingredients can be avoided. Patch testing may also reveal additional allergens. Our patient was also found to be allergic to bacitracin, influencing future antibiotic choice for this patient. Alternatives to Mastisol may include another liquid adhesive like compound tincture benzoin (CTB), but numerous studies have noted that Mastisol has a lower incidence of postoperative contact dermatitis than $\mathrm{CTB}^{9}$ and is a less potent sensitizer to reaction in part owing to its superior adhesive qualities. ${ }^{10-12}$ Moreover, the use of CTB after reaction to Mastisol may not be appropriate because CTB contains some of the same ingredients as Mastisol (e.g., styrax). Notably, both of these adhesives may have cross-reactivity with other allergens, such as balsam of Peru and colophony, which are found in many common products. ${ }^{10}$ Thus, it may be wise to avoid both in patients with spina bifida and to choose dressings judiciously, with minimal possible irritants.

Interventionists should be aware of the possibility of acute contact dermatitis in patients with spina bifida when using Mastisol. Additionally, future studies should investigate the possible relationship between history of latex allergy and sensitization to Mastisol because these findings may have wider impact on the population of patients with spina bifida.

\section{References}

1. Copp AJ, Adzick NS, Chitty LS, et al. Spina bifida. Nat Rev Dis Primers. 2015;1(1):15007.

2. Cremer R, Hoppe A, Korsch E, et al. Natural rubber latex allergy: prevalence and risk factors in patients with spina bifida compared with atopic children and controls. Eur J Pediatr. 1998;157(1): 13-16.

3. Engibous PJ, Kittle PE, Jones HL, Vance BJ. Latex allergy in patients with spina bifida. Pediatr Dent. 1993;15(5):364-366.

4. Ezeh UE, Price HN, Belthur MV. Allergic contact dermatitis to Mastisol adhesive used for skin closure in orthopedic surgery: a case report. J Am Acad Orthop Surg Glob Res Rev. 2018;2(9): e037.

5. Kline A. Allergic contact dermatitis of the foot after use of Mastisol skin adhesive: a case report. Foot Ankle J. 2008;1(2):2.

6. Worsnop F, Affleck A, Varma S, English J. Allergic contact dermatitis from Mastisol mistaken for cellulitis. Contact Dermat. 2007;56(6):357-358.

7. Bernardini R, Novembre E, Lombardi E, et al. Risk factors for latex allergy in patients with spina bifida and latex sensitization. Clin Exp Allergy. 1999;29(5):681-686.

8. Kelly KJ, Pearson ML, Kurup VP, et al. A cluster of anaphylactic reactions in children with spina bifida during general anesthesia: epidemiologic features, risk factors, and latex hypersensitivity. J Allergy Clin Immunol. 1994;94(1):53-61.

9. Lesesne CB. The postoperative use of wound adhesives. Gum mastic versus benzoin, USP. J Dermatol Surg Oncol. 1992;18(11): 990.

10. Hood CR Jr, Cornell RS, Greenfield B. Liquid adhesive contact dermatitis after bunionectomy: a case report and literature review. J Foot Ankle Surg. 2016;55(1):209-214.

11. Caldwell $M$, Walega $D$. Mastisol induced allergic contact dermatitis. J Pain. 2012;13(4):S26

12. Mabrie DC, Papel ID. An unexpected occurrence of acute contact dermatitis during rhinoplasty. Arch Facial Plast Surg. 1999;1(4): 320-321. 


\section{Disclosures}

The authors report no conflict of interest concerning the materials or methods used in this study or the findings specified in this paper.

\section{Author Contributions}

Conception and design: Bowman, Lam. Acquisition of data: Bowman, Lam. Analysis and interpretation of data: all authors. Drafting the article: Bowman, Thirunavu. Critically revising the article: all authors. Reviewed submitted version of manuscript: all authors. Approved the final version of the manuscript on behalf of all authors: Bowman. Administrative/technical/ material support: Bowman, Lam. Study supervision: Bowman, Lam.

\section{Correspondence}

Robin M. Bowman: Ann and Robert H. Lurie Children's Hospital of Chicago, Chicago, IL. rbowman@luriechildrens.org. 